\title{
Growth performance of nile tilapia (Oreochromis niloticus) fingerlings fed on soybean (Glycine max) compared to dagaa (Rastrineobola argentea) meal with diet supplement of maize bran.
}

\author{
Musa Ogola, Dickson Otieno Owiti, Javan Ominde* \\ Department of Fisheries and Natural Resources, Maseno University, Maseno, Kisumu, Kenya
}

\begin{abstract}
A study was conducted at Maseno University to evaluate the growth performance of Nile tilapia (Oreochromis niloticus) fingerlings fed on soybean (Glycine max) and dagaa (Rastrineobola argentea) meals separately. The experimental feeds used were Glycine max and Rastrineobola argentea. A total of $\mathbf{1 6 0}$ fingerlings were used during this experiment. The fingerlings were fed at $5 \%$ of their mean body weight on daily basis for 5 weeks and the feed amount adjusted after every sapling in relation to body weight. There were 2 replicates for each feed therefore 4 hapas were used hence 40 fingerlings for each hapa net. The concrete pond used was drained and left to dry for $\mathbf{4}$ days to kill any available parasites before filling with water. After filling the pond with water, it was fertilized using DAP to promote the growth of phytoplankton in the water before stocking with the fingerlings. Sampling was done weekly to determine SGR and FCR of the fingerlings from each hapa. Statistical analysis was done using SPSS v. 16.02. Although there was observable difference, statistically there was no significant difference between the two treatments. In weight $p=0.73(p>0.05)$ and length $p=0.61(p>0.05)$. The average temperature during the project period was $24.4^{\circ} \mathrm{C}+/-0.33$ while the $\mathrm{pH}$ was $8.87+/-0.28$.
\end{abstract}

Keywords: Glycine max, Phytoplankton, Oreochromis niloticus, DAP, FCR, SPSS, SGR

Accepted on $17^{\text {th }}$ December, 2019

\section{Introduction}

\section{Background information}

Tilapia is mainly lacustrine fish species and is adapted to enclosed waters. Nile Tilapia (oreochromis niloticus) is named as the 'food for fish of the 21 st century' and is the most important farmed fish worldwide. Nile Tilapia is a prolific breeder with mature ones breeding after every 2- 3 weeks fast growing, resistant to disease and handling and are able to tolerate a wide range of environmental conditions. They are widely cultured in tropical and sub-tropical regions of the world and constitute the third largest farmed finfish with annual production growth rate of about $11.5 \%$ [1]

Global production of farmed tilapia has increased from 186,544 Mt to $659,000 \mathrm{Mt}$ representing $4.48 \%$ of total farmed finfish in 1995. In Kenya Nile Tilapia accounts for about $75 \%$ of cultured fish species [2]. Aquaculture systems for Nile Tilapia include ponds (earthen, lined or cemented), tanks, dams and cages in lakes. As the aquaculture industry expands and technology development continues, traditional extensive culture of tilapia is being replaced by semi-intensive and intensive production systems.

\section{Statement of the problem}

The culture of Nile Tilapia has largely depended on animals as protein sources during formulation of feeds. Nile Tilapia requires more protein during its early stages of development (fry-fingerling stage). In East Africa, dried silver cyprinid (Rastrineobola argentea: common names: mukene, dagaa, omena), an indigenous pelagic fish species from Lake Victoria, is used as fishmeal. However, there is an increasing demand for $R$. argentea for human consumption. Furthermore, sun-dried $R$. argentea FM undergoes peroxidation during storage which may create off flavours, reduce growth and in extreme cases cause mortalities $[3,4]$. Hence there was need to search for alternative protein sources.

\section{Hypothesis}

There is no significant difference in the performance of Oreochromis niloticus fingerlings.

\section{Justification}

This experiment was important since there is a need to replace animal fish meals with plant protein as raw materials for feed formulation. A number of organizations are also against fish feeding fish.

\section{Objective of the Study}

General objective

To experiment the growth performance of soybean meal on Oreochromis niloticu fingerlings.

Specific objectives

- To determine the FCR of Nile Tilapia fed soybean meal 
Citation: Ogola M, Owiti DO, Ominde J. Growth performance of nile tilapia (Oreochromis niloticus) fingerlings fed on soybean (Glycine max) compared to dagaa (Rastrineobola argentea) meal with diet supplement of maize bran. J Fish Res 2020;4(1): 14-20.

- To determine the growth rate of Nile Tilapia fingerlings fed soybean meal.

\section{Literature Review}

\section{Diversity and distribution of freshwater fishes}

Fish are very diverse animals and can be categorized in many ways. This article is an overview of some of the ways in which fish are categorized. Although most fish species have been discovered described, 33100 species of fish have been described by April 2015.That is more than the combined total of all other vertebrate species: mammals, amphibians, reptiles and birds.

According to Kotellat and Whitten, around 3500 species of freshwater fishes can be found in Asia [5]. In the world, diversity of freshwater fish is the greatest in tropical Southeast Asia water bodies. A report stated that phylogenetic relationship between freshwater fish in Borneo and freshwater fish in Thailand, India and China shows related relationship. The first recognized taxonomic description of fish of Kenya began in 18th century says the writers as recorded in 1758 in Systems Nature edited by C.Linnaues. But the description and naming of majority of fresh water fishes of Kenya took place during 19th Century. The biggest local fresh water lakes are Victoria (Kenya has only 6\% of its water) and lake Naivasha while the salt water ones are lake Turkana, Nakuru, Elementaita, Magadi and Natron, all in the expansive Rift Valley region. On the other hand Kenya's main rivers are Tana, Athi, Nyando, Nzioa, Mara, Kuja and Sondu Miriu among others.

Freshwater fish species are usually classified by the water temperature in which they survive. The water temperature affects the amount of oxygen available as cold water contains more oxygen than warm water. Freshwater fish are those that spend some or all of their lives in fresh water, such as rivers and lakes, with a salinity of less than $0.05 \%$. These environments differ from marine conditions in many ways, the most obvious being the difference in levels of salinity. To survive fresh water, the fish need a range of physiological adaptations. $41.24 \%$ of all known species of fish are found in fresh water. This is primarily due to the rapid speciation that the scattered habitats make possible. When dealing with ponds, rivers and lakes, one might use the same basic models of speciation as when studying island biogeography.

Freshwater fish differ physiologically from salt water fish in several respects. Their gills must be able to diffuse dissolved gasses while keeping the salts in the body fluids inside. Their scales reduce water diffusion through the skin: freshwater fish that have lost too many scales will die. They also have well developed kidneys to reclaim salts from body fluids before excretion.

Coldwater fish species survive in the coldest temperatures, preferring a water temperature of $50^{\circ} \mathrm{F}\left(10^{\circ} \mathrm{C}\right)$ to $60^{\circ} \mathrm{F}\left(16^{\circ} \mathrm{C}\right)$ degrees. In North America, air temperatures that result in sufficiently cold water temperatures are found in the northern United States, Canada, and in the southern United States at high elevation. Common cold water fish include brook trout, rainbow trout, and brown trout.

Warm water fish species can survive in a wide range of conditions, preferring a water temperature around $80^{\circ} \mathrm{F}\left(27^{\circ} \mathrm{C}\right)$. Warm water fish can survive cold winter temperatures in northern climates, but thrive in warmer water. Common warm-water fish include largemouth bass, bluegill, catfish, and crappies.

Cool water fish species prefer water temperature between the cold-water and warm-water species, around $60^{\circ} \mathrm{F}\left(16^{\circ} \mathrm{C}\right)$ to $80^{\circ} \mathrm{F}\left(27^{\circ} \mathrm{C}\right)$. They are found throughout North America except for the southern portions of the United States. Common coolwater species include muskellunge, northern pike, walleye, and yellow perch.

\section{Feeding}

Protein requirements of Nile Tilapia differ with each life stage of the fish [6]. According to their study, the fry and fingerlings require a diet in high protein, lipids, vitamins and mineral and lower in carbohydrates. Adult fish need more calories from fats and carbohydrates for basal metabolism and a smaller percentage of protein for growth.

Fish do not have true protein requirement but need a wellbalanced mixture of indispensable and dispensable amino acids [7]. Inadequate intake of protein results in retardation or cessation of growth due to the withdrawal of protein from less vital tissues to maintain the function of more vital ones. If too much protein is supplied, only part will be converted to energy. For fry (approximately $0.5 \mathrm{~g}$ ) dietary protein levels ranging from $36-50 \%$ have shown to produce maximum growth $[1,6-9]$. For juveniles (approximately $0.5-5 \mathrm{~g}$ ) $29-40 \%$ has been determined to produce optimal growth [6,10-13]. Young adult fish (up to 40 g) $27-35 \%$ protein appears to be optimal $[14,15]$. According to Lim, commercial diets formulated for Tilapia constitute $24-28 \%$ protein as natural pond foods contribute a significant amount of protein so this level is assumed to be high enough [16].

Natural pond organisms are the only the only source of nutrients for the growth of in extensive culture systems. In semi-intensive farming system, supplemental diets, which consist of locally available, low cost single foodstuffs such as rice bran, maize meal, coffee pulp and/or their combination are generally used as supplement to natural feeds [16]. As stocking rates increases, the contribution of natural foods decrease and more nutritionally complete diets are needed. In semi-intensive and intensive systems, diets are the most expensive cost item, often ranging from $30-60 \%$ of the total variable expenses depending on the intensity of the culture operations.

A number of alternative protein sources for Nile tilapia feed have been tested. Most of these raw materials are derived from different plant sources [17-19].

According to Jackson et al., feeding trials were done using corpa, groundnuts, soya, sunflower, rapeseed, cottonseed and leucaena meals on tilapia (Sarotherodon mossambicus). All protein sources except leucaena promoted reasonable growth even at high dietary inclusion level. At $25 \%$ plant protein level, the diets containing oil-seed meals supported comparable growth to the fishmeal controls in all three trials; at 50\% level, growth rates were lower in corpa, groundnut and soya [20].

Feeding trial conducted to evaluate the effects of substituting animal protein with a mixture of plant feedstuffs with torula 
yeast, $20 \%$ soybean and $15 \%$ Alfalfa Leaf Protein Concentrate in diets for tilapia (Oreochromis mossambicus Peters) fry. Diet nutritional quality was very similar independent of composition with no diference in growth parameters, but fish fed with $30 \%$ yeast diet showed the best growth performance. Protein digestibility was above $80 \%$ for all diets. The best incidence cost with $25 \%$ yeast and the highest profit index with $30 \%$ yeast, but no statistical differences were observed with the other treatments. These results suggests that it is possible to replace up to $60 \%$ of animal protein with a mixture of plant proteins, including 30\% torula yeast in tilapia fry diets without adverse effects on performance and culture profit [21].

\section{Materials and Methods}

\section{Study area}

This experiment was done in the School of Agriculture and Food Security at Maseno University located along Kisumu Busia road.

\section{Experimental fish}

The experimental fish used was Nile tilapia (Oreochromis niloticus) fingerlings.

\section{Experimental setup}

This experiment was conducted for a period of 5 weeks. A total number of 160 fingerlings used were obtained from fish seed production unit at Pioneer Fish Farm in Lela. The fingerlings were divided into 4 groups (40 each) and placed into 4 hapas. The concrete pond used was drained and left to dry for some days to kill any available parasites before stocking. The fingerlings were fed 3 times daily at $5 \%$ body weight; in the morning at $9 \mathrm{am}$, afternoon at 12:30 pm and in the evening at 4:30 pm (Figure 1).

\section{Experimental diet}

The experimental diets used to evaluate the performance of Oreochromis niloticus fingerlings were soybean meal and Rastrineobola argentea meal. The diets were formulated using maize brans to provide energy using the simple Pearson square method at $35 \%$ crude protein for each. Dry soybean seeds were heated over a pan and milled. Dagaa was sundried and milled for incorporation into feed formulations (Figure 2).

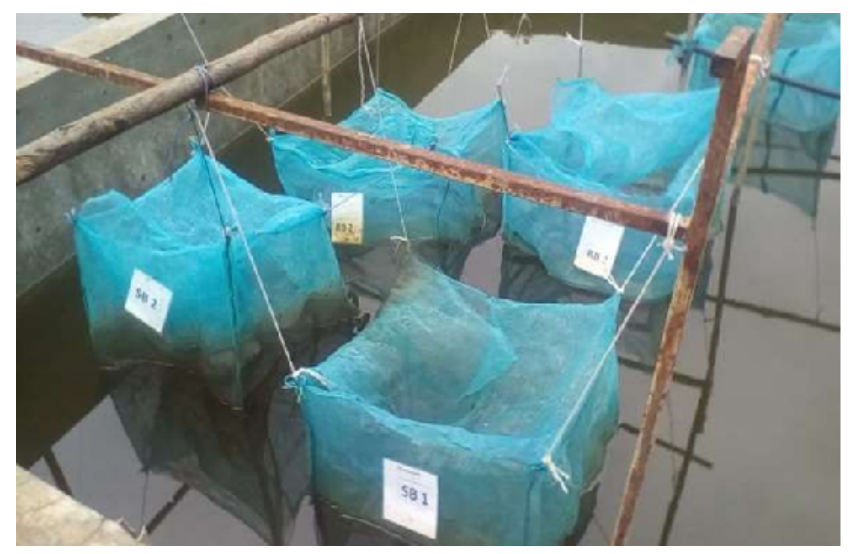

Figure 1. Experimental design.

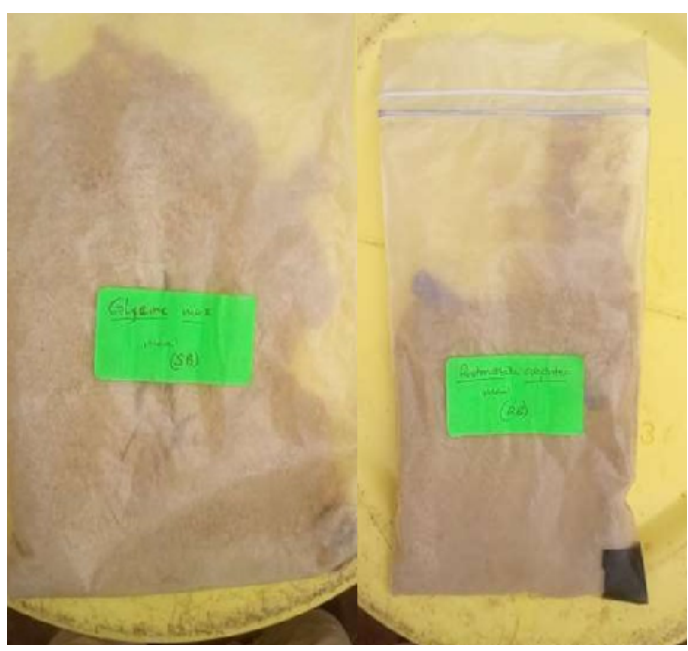

Figure 2. Experimental feeds.

\section{Feeding regimes}

Hapa labeled RB1 and RB2 were fed fish feed containing Rastrineobola argentea while hapas labeled SB1 and SB2 fed fish feed containing Glycine max at 5\% bodyweight of the fingerlings. Feed amount was adjusted after every sampling in relation to mean body weight.

\section{Materials}

The materials used during the experiment include:

- 160 Oreochromis niloticus fingerlings

- 4 hapa nets

- Electronic weighing scale

- Sieve

- Buckets

- Soybeans

- Rastrineobola argentea

- Maize bran

- Length board

\section{Sampling method}

Sampling was done on a weekly basis. Fingerlings were not fed in the afternoon before the sampling day and in the morning of the sampling day before sampling. This was to allow the fish to empty their gut for accurate weight and also reduce stress due to handling during sampling. Collective weighing of the fingerlings was done to obtain the average weight. However, only five fingerlings picked randomly were measured for total length in order to reduce stress due to handling.

\section{Data Collection}

\section{Fish growth}

In order to assess the growth performance, records of individual fish weights were taken from each hapa weekly. A sensitive electronic balance (KERN-EB 2-200) was used to weigh the sampled fish. All the fish were weighed and returned to their respective hapas. Specific growth rates and Food convention rate was calculated on a weekly interval after each sampling. 
Citation: Ogola M, Owiti DO, Ominde J. Growth performance of nile tilapia (Oreochromis niloticus) fingerlings fed on soybean (Glycine max) compared to dagaa (Rastrineobola argentea) meal with diet supplement of maize bran. J Fish Res 2020;4(1): 14-20.

Specific Growth Rates assumes that fish weight increases exponentially and it was recommended for reporting the growth of small fish cultured for short periods such as in this study.

\section{Water quality parameters}

Water quality parameter measured included temperature and $\mathrm{pH}$. Temperature was measured in degrees Celsius. Temperature and $\mathrm{pH}$ were measured at $5 \mathrm{~cm}$ depth using pHep by HANNA.

\section{Statistical Analysis}

Statistical data analysis was done using excel and SPSS version 16.02, where performance in growth of $O$. niloticus cultured under different diet treatments were analyzed (Tables 1-3).

\section{Results}

The Growth performance of $O$. niloticus fingerlings fed on different diets is illustrated in Table 1.The overall performance of the study showed that fish fed dagaa meal performed better than those fed soybean meal. SGR of fish fed dagaa increased from the stocking period up to week 4 then reduced in week 5 while the SGR of fish fed soybean meal increased up to week 3 and started reducing on week 4 (Table 4). The FCR of fish fed

Table 1. Weight and length group statistics.

\begin{tabular}{|c|c|c|c|c|}
\hline VAR00001 & N & Mean & Std. Deviation & $\begin{array}{c}\text { Std. Error } \\
\text { Mean }\end{array}$ \\
\hline WEIGHT 1 & 5 & 0.844 & 0.43776 & 0.19577 \\
\hline 2 & 5 & 0.756 & 0.34078 & 0.1524 \\
\hline LENGHT 1 & 5 & 35.7 & 7.54255 & 3.37313 \\
\hline 2 & 5 & 33.42 & 5.95542 & 2.66334 \\
\hline
\end{tabular}

dagaa meal was much lower in week 2, 4 and 5 (Figures 3 and 4).

\section{Water quality variables}

Water quality parameters that could be measured were temperature and $\mathrm{pH}$ (Tables 5-9). The results show that average weekly temperature was almost constant at $24.40+/-0.33 . \mathrm{pH}$ however varied with as high as averagely 9.23 in week 5 (Figure 5).

\section{Discussion}

In the present study, feeding experiment was aimed at comparing the performance of $O$. niloticus fingerlings fed soybean (44\% crude protein) meal and dagaa $(58.7 \%$ crude protein) meal. Protein is very important in fish growth and thus a crucial ingredient in fish diets. The results of this study shows that growth rate of fish fed dagaa meal (RB) increases up to week 4 and then reduces on week 5 while those fed soybean meal (SB) increases up to week 3 and then reduces in week 4 and 5. With respect to specific growth rates, O. niloticus fingerlings fed dagaa meal showed a higher performance than those fed soybean meal.

However there was no significant difference in SGR on the first week of the experiment. In developing countries, fishmeal, which forms the potential base for artificial feeds, is scarce and expensive [14]. Thus, research on using locally available plant protein sources in the production of high-quality fish feed is required. The availability of such feeds will contribute into sustainable development of Aquaculture in Africa. The results from the present study suggest that soybean may be used to replace fishmeal in fish feed. This is because the use of soybean

Table 2. Length and weight independent samples test.

\begin{tabular}{|c|c|c|c|c|c|c|c|c|c|}
\hline & \multicolumn{2}{|c|}{$\begin{array}{l}\text { Levene's Test for } \\
\text { Equality of Variances }\end{array}$} & \multicolumn{7}{|c|}{ t-test for Equality of Means } \\
\hline & \multirow[t]{2}{*}{$\mathbf{F}$} & \multirow{2}{*}{ Sig. } & \multirow[t]{2}{*}{$\mathbf{t}$} & \multirow{2}{*}{ df } & \multirow[t]{2}{*}{ Sig. (2- tailed) } & \multirow{2}{*}{$\begin{array}{c}\begin{array}{c}\text { Mean } \\
\text { Differenc }\end{array} \\
e\end{array}$} & \multirow{2}{*}{$\begin{array}{c}\text { Std. Error } \\
\text { Differenc e } \\
\text { e }\end{array}$} & \multicolumn{2}{|c|}{$\begin{array}{l}\text { 95\% Confidence Interval of the } \\
\text { Difference }\end{array}$} \\
\hline & & & & & & & & Lower & Upper \\
\hline Equal variances assumed & 0.501 & 0.499 & 0.355 & 8 & 0.732 & 0.088 & 0.2481 & -0.48411 & 0.66011 \\
\hline Equal variances not assumed & & & 0.355 & 7.546 & 0.733 & 0.088 & 0.2481 & -0.49016 & 0.66616 \\
\hline Equal variances not assumed & 0.381 & 0.554 & 0.53 & 8 & 0.61 & 2.28 & 4.29784 & -7.63083 & 12.19083 \\
\hline Equal variances not assumed & & & 0.53 & 7.592 & 611 & 2.28 & 4.29784 & -7.72442 & 12.28442 \\
\hline
\end{tabular}

Table 3. $p H$ and temperature group statistics.

\begin{tabular}{|c|c|c|c|c|}
\hline & VAR00 $\mathbf{0 0 1}$ & & Mean & Std. Deviation \\
\hline & & N & Std. Error Mean & 0.28155 \\
\hline pH & 1 & 5 & 0.12591 &. \\
\hline TEMP & 2 & 0 a & 24.4 & 0.32764 \\
\hline
\end{tabular}

Table 4. Weekly Specific Growth Rate and Food Conversion Ratio.

\begin{tabular}{|c|c|c|c|}
\hline Week & Variables & Diets \\
\hline & & RB \\
\hline 1 & SGR & 1.269643 \\
\hline & FCR & 1.102672 \\
\hline & SGR & 2.205357 \\
\hline & FCR & 0.838866 & 1.307143 \\
\hline & SGR & 3.478571 \\
\hline
\end{tabular}




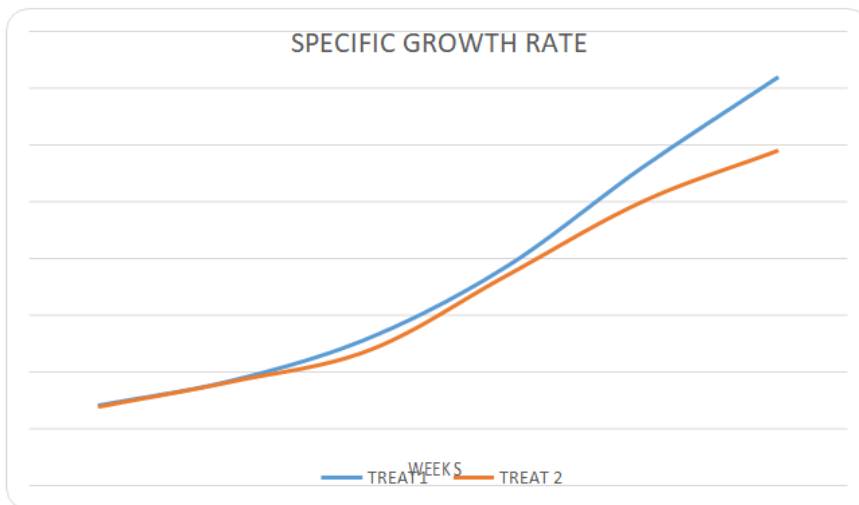

Figure 3. A graph showing specific growth rate.

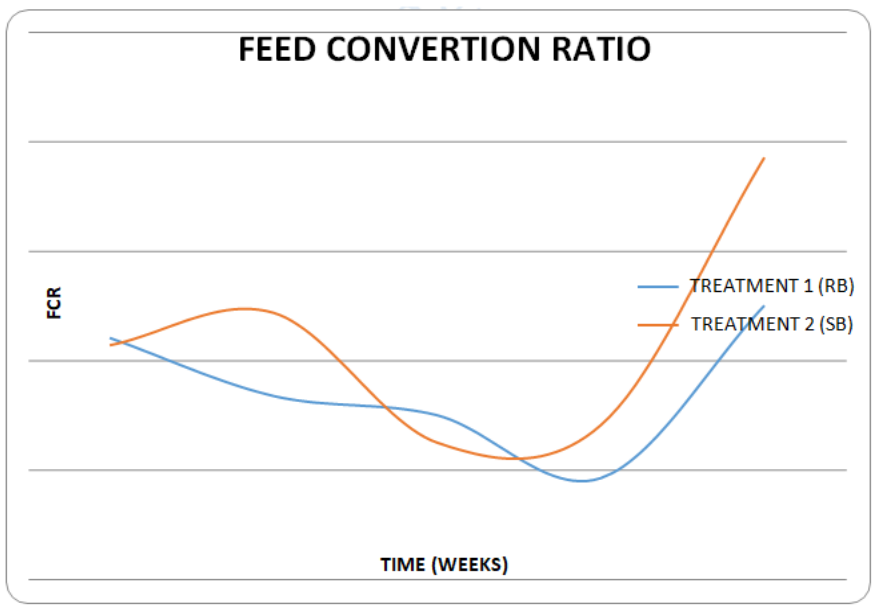

Figure 4. Graph showing performance in FCR.

to culture $O$. niloticus has yielded positive results. Moreover soybean is cheaper compared to dagaa.

FCR greater than 2 more often than not results in loses. This is because a large percentage of one's operational costs are spent on buying feeds. FCR is simultaneously influenced by the quality of feed given, the fish themselves, pond water quality and feeding management. These factors act together and determine the fish's appetite as well as how much of the feed eaten is actually digested and used for growth. Hence these factors collectively determine what the FCR shall be at any given time.

It is seen from the present study that $O$. niloticus fingerlings fed on soybean meal gave lower specific growth rate and FCR compared to those fed on dagaa meal. The present results agree with the findings of other workers [12,22,23]. According to reports that fish fed on diets containing heat-treated soyabeans weighed significantly less and suffered higher mortality than those fed on fishmeal control diet. Fowler (1980) further noted that as the level of soyabean meal was increased and that of fishmeal decreased in the diet, growth rate was slower, regardless of degree of heat treatment. Vanketesh et al. and Ray and Patra reported retardation in growth of Clarias batrachus (Linn) and Anabas testudiness when fed on soybeans [22,23]. Dabrowski and Kozak reported that Grass carp fry fed with soybean meal showed poor growth performance than when fed with fishmeal [24]. With increasing levels of dietary soyabean cake, growth
Table 5. Weekly water quality parameter.

\begin{tabular}{|c|c|c|}
\hline Week & Variables & \\
\hline 1 & Temperature & 24.32 \\
\hline 2 & $\mathrm{pH}$ & 8.78 \\
\hline & Temperature & 24.29 \\
\hline 3 & $\mathrm{pH}$ & 9.07 \\
\hline & Temperature & 24.93 \\
\hline 4 & $\mathrm{pH}$ & 8.74 \\
\hline 5 & Temperature & 24.42 \\
\hline & $\mathrm{pH}$ & 8.52 \\
\hline & Temperature & 24.04 \\
\hline
\end{tabular}

Table 6. Mortalities.

\begin{tabular}{|l|c|c|c|c|}
\hline & Treatment 1 & & Treatment 2 & \\
\hline & RB1 & RB2 & SB1 & SB2 \\
\hline WEEK 1 & 0 & 0 & 0 & 0 \\
\hline WEEK 2 & 0 & 0 & 0 & 0 \\
\hline WEEK 3 & 0 & 0 & 0 & 0 \\
\hline WEEK 4 & 1 & 0 & 0 & 1 \\
\hline WEEK 5 & 0 & 4 & 0 & 1 \\
\hline
\end{tabular}

Table 7. Treatment 1 weekly feeding ration.

\begin{tabular}{|l|c|c|c|c|}
\hline Treatment 1 & RB1 & & RB2 & \\
\hline & $\begin{array}{c}\text { Daily } \\
\text { Feeds }\end{array}$ & $\begin{array}{c}\text { Each Feeding } \\
\text { time }\end{array}$ & $\begin{array}{c}\text { Daily } \\
\text { Feeds }\end{array}$ & $\begin{array}{c}\text { Each Feeding } \\
\text { Time }\end{array}$ \\
\hline Week & & & & \\
\hline 1 & 0.54 & 0.18 & 0.58 & 0.19 \\
\hline 2 & 0.73 & 0.24 & 0.75 & 0.25 \\
\hline 3 & 0.98 & 0.33 & 1.11 & 0.37 \\
\hline 4 & 1.42 & 0.47 & 1.65 & 0.55 \\
\hline 5 & 2.04 & 0.68 & 2.39 & 0.8 \\
\hline
\end{tabular}

Table 8. Treatment 2 weekly feeding rations.

\begin{tabular}{|l|c|c|c|c|}
\hline Treatment 2 & SB1 & & SB2 & \\
\hline & $\begin{array}{c}\text { Daily } \\
\text { feeds }\end{array}$ & $\begin{array}{c}\text { Each feeding } \\
\text { time }\end{array}$ & $\begin{array}{c}\text { Daily } \\
\text { Feeds }\end{array}$ & $\begin{array}{c}\text { Each feeding } \\
\text { time }\end{array}$ \\
\hline Week & & & & \\
\hline 1 & 0.54 & 0.18 & 0.58 & 0.19 \\
\hline 2 & 0.73 & 0.24 & 0.77 & 0.26 \\
\hline 3 & 0.97 & 0.32 & 0.95 & 0.32 \\
\hline 4 & 1.53 & 0.51 & 1.46 & 0.49 \\
\hline 5 & 2.15 & 0.72 & 1.8 & 0.6 \\
\hline
\end{tabular}

Table 9. Average weight and length sample data.

\begin{tabular}{|c|c|c|}
\hline \multicolumn{3}{|l|}{ Means } \\
\hline & Treatment 1 & Treatment 2 \\
\hline & $\mathrm{RB}$ & SB \\
\hline Sample size & 40 & 40 \\
\hline Total weight & 29.26167 & 26.80333 \\
\hline \multicolumn{3}{|l|}{ Average weight } \\
\hline & 0.750215 & 0.676956 \\
\hline Length 1 & 33.33333 & 33.91667 \\
\hline 2 & 35.16667 & 30.33333 \\
\hline 3 & 33.75 & 33.16667 \\
\hline 4 & 32.91667 & 30.66667 \\
\hline 5 & 33.16667 & 30.08333 \\
\hline Total & 168.3333 & 158.1667 \\
\hline \multicolumn{3}{|l|}{ average length } \\
\hline & 33.66667 & 31.63333 \\
\hline
\end{tabular}




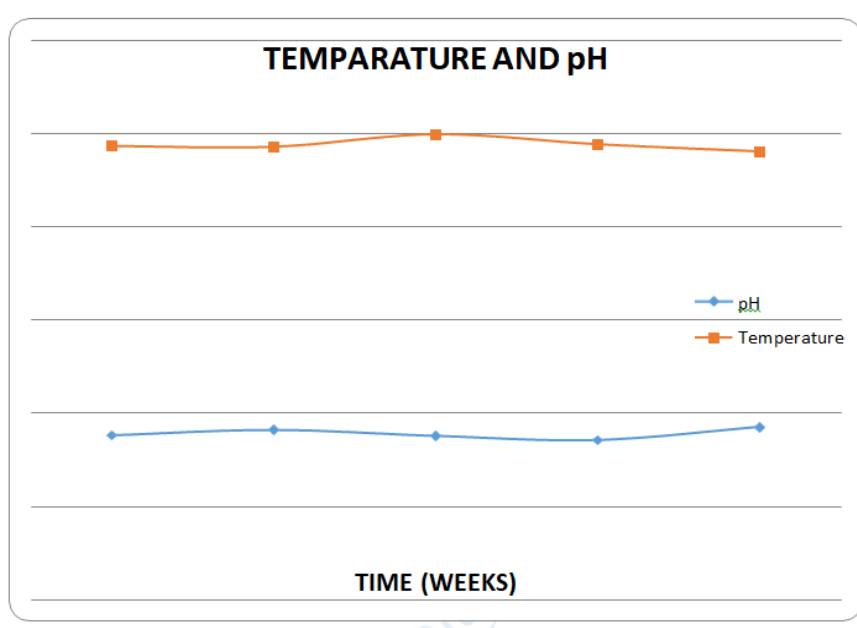

Figure 5. Water quality parameter.

rate and feed utilization decreased in the Chinese longsnout catfish [25]. Detrimental effects on growth performance were obvious when half of the fish meal protein was replaced by soyabean protein in diets of juvenile cobia Rachycentron canadum [26].

It is speculated that the heat treatment applied to soybeans in the present study was probably inadequate to the enzymes that inhibit the digestion of leguminous plant protein in fish [27]. But it has been recommended that, the anti-nutritional factors other than trypsin inhibitors contained in soybean meal may be removed by sufficient heat treatment $[13,28]$. According to reports low growth rate in chinook and coho salmon fed on heattreated soyabean diet with temperature range of 178 to $278^{\circ} \mathrm{C}$. The observations of reports support the speculation that the heat applied in the present study to treat soyabeans was not sufficient enough to destroy the anti-nutritional factors. However, though soybean diet performed relatively poor than the other diets in the present study, the FCR were relatively better than those reported by Nandeesha et al. [29]. The FCR in the present study ranged from 0.62 to 1.92 . Nandeesha et al. obtained a much higher FCR in 'major carp', Catla catla (Ham.) fed on soybean meal with FCR of 3.64 [29]. Portella et al. reported that artificial diets containing soybean oil promoted good growth in fingerlings [30]. The good FCR obtained from O. niloticus fingerlings fed on soybean diet in the present study suggests that soybean meal containing diets can be another alternative replacement to fishmeal. However, it is recommended here that the optimum temperature for destroying the anti-nutritional factors in soybeans without impairing other nutrients such as amino acids should be established.

In the present study, it was initially thought that fingerlings fed on soybean meal would produce the best performance compared to those fed dagaa meal. However, the study shows that the FCR of $O$. niloticus fingerlings fed dagaa meal was lower than those fed on soybean meal. This indicates that dagaa meal had better performance although generally fingerlings fed soybean meal also had a good FCR. Generally fish 'dagaa' meal bears high nutritional qualities and biological values and is well balanced on amino acid profile yet lacks anti- nutritional factors. As such, it is the most loved protein source by most aqua feed producing industries [31]. Fish meal is more digested and assimilated ingredient than the plant source ingredients.

In the present study, it is noted that the $\mathrm{pH}$ is in the recommended range of 9.0 - 6.5. This is according to ECE standard statistical classification of surface freshwater quality for the maintenance of aquatic life. In the last week of the experiment the average $\mathrm{pH}$ was 9.2 with as high $\mathrm{pH}$ as 10.0 during the days other week. This could have led to the high mortalities recorded in that week. Temperature on the other hand was almost constant throughout.

\section{Conclusion and Recommendations}

\section{Conclusion}

Growth performance of $O$. niloticus fingerlings showed no significant difference between soybean meal and dagaa meal. Therefore soybean can be used as a total replacement of fish meal for $O$. niloticus fingerlings. This would therefore help in reducing the cost of feeds since soybean is cheaper and more readily available.

\section{Recommendations}

However soybean can be used to replace fish meal, it is recommended that the optimum temperature for destroying antinutritional factors found in soybean seeds without impairing the nutrients such as amino acids should be established.

\section{References}

1. Sayed AFME, Teshima SI. Protein and energy requirements of Nile tilapia, Oreochromis niloticus, fry. Aquaculture. 1992; 103: 55-63.

2. Mbonge MJ, Dae KJ, Ochieng OE. An Overview of Kenyan Aquaculture: Current Status, Challenges, and Opportunities for Future Development. Fish Aquat Sci. 2017; 17: 1-11, 31.

3. Prabhu AJ, Sharma P, Mariojouls JW, et al. Post-prandial changes in plasma mineral levels in rainbow trout fed a complete plant ingredient based diet and the effect of supplemental di-calcium phosphate. Aquaculture. 2014: 430: $220-227$.

4. Bell JG, Henderson RJ, Tocher DR, et al. Substituting fish oil with crude palm oil in the diet od atlantic salmon (Salmos) affects muscle fatty acids compostion and hepatic fatty acid metabolism. J Nutr. 2002; 132: 222-230.

5. Kottelat M, Whitten T. Freshwater biodiversity in Asia, with special reference to fish. World Bank Tech Pap. 1996; 343: 359.

6. Kim J, Ross B. A Guide To Tilapia Feeds and Feeding, Scotland, Institute of Aquaculture. 1982. 111: 0-901636-47-9.

7. SY Shiau, Nutrient Requirements and Feeding of Finfish for Aquaculture; 2002. Adv Cycl Nucleot Res. 1978; 9: 253- 263.

8. AT Davis; RR Stickney, Growth responses of Tilapia aurea to dietary protein quality and quantity, 1978.

9. Santiago CB, Laron MA. Proceedings of the Fourth Asian Fish Nutrition Workshop. Andhra Pradesh India, 1991; 55-62.

10. Cruz EM, Laudencia IL. Kalikasan, The Philippine J boil. 1977. 
11. Mazid MA, Tanaka Y, Katayama T, et al. Growth response of Tilapia zillii fingerlings fed isocaloric diets with variable protein levels. Aquaculture. 1979; 18: 115-122.

12. Fowler LG. Substitution of soyabean and cotton seed products for fish meal in diets fed to Chinook and Coho Salmon. Prog Fish Cult 1980; 42: 87-91.

13. Wilson RP, Poe WE. Effects of feeding soyabean meal with varying trypsin inhibitor activities on growth of fingerlings of channel catfish. Aquaculture. 1985; 46: 19-25.

14. Siddiqui AQ, Howlader MS, Adam AA, Effects of dietary protein levels on growth, feed conversion and protein utilization in fry and young Nile tilapia, Oreochromis niloticus. Aquaculture. 1988; 70: 63-73.

15. Xie S, He X, Yang Y. Effects on growth and feed utilization of Chinese longsnout catfish Leiocassis longirostris Gunther of replacement of dietary fishmeal by soybean cake. Aquacult Nutr. 1988; 4:187-192.

16. C Lim. Nutrition and feeding of fish, 1989.

17. Abowei JFN, Ekubo AT. A review of conventional and unconventional feeds in fish nutrition. $\mathrm{Br} \mathrm{J}$ Pharmacol Toxicol. 2011; 25:179-191.

18. Silva SD, Gunasekera RM, Atapattu D, The dietary protein requirements of young tilapia and an evaluation of the least cost dietary protein levels. Aquacu. 1989; 80: 271-284

19. Jamu DM, Ayinla OA. Potential for the development of aquaculture in Africa. NAGA, World Fish Center Quarterly. 2003; 26: 9-13.

20. Jackson AJ, Capper BS, Matty AJ. Evaluation of some plant proteins in complete diets for the tilapia Saotherodon mossambicus. Aquacul. 1982; 27: 97-109.

21. Olvera-Novoa MA, Martinez-Palacio CA, Castillo LO. Utilization of torula yeast (Candida utilis ) as a protein source in diets for tilapia (Oreochromis mossambicus Peters) fry. 2002; 8: 257-264.

22. Vanketesh B, Mukherji AP, Mukhopadhyay PK. Growth and metabolism of the cat fish. Clarias batrachus (Linn.) fed with different experimental diets. Proc Indian Nat Sci Acad. 1986; 95: 457-462.

23. Ray AK, Patro BC. Growth response, feed conversion and metabolism of the air breathing, Anabas testudiness (Bloch) to different dietary protein sources. In: Fish Nutrition Research in Asia. De Silva SS (ed) Proceedings of the third Asian Fish Nutrition Network meeting. Asian Fisheries Society Special Publication, Manila, Phillipines. 1989; 4: 123-129.

24. Dabrowski K, Kozak B. The use of fish meal and soyabean meal as protein source in the diet of grass carp fry. Aquacul. 1979; 16: 107-114.

25. Xie S, X He, Yang Y. Effects on growth and feed utilization of Chinese longsnout catfish Leiocassis longirostris Gunther of replacement of dietary fishmeal by soybean cake. Aquacult Nutr. 1989; 4:187-192.

26. Chou RL, Her BY, Su MS, et al. Substituting fishmeal with soyabean meal in diets of juvenile cobia Rachycentron canadum. Aquacul. 2004; 229: 325-333.

27. Smith RR. Recent research involving full-fat soyabean meal in salmonid diets. Salmonid. 1977; 1: 8-11.

28. Spinelli JC, Manken C, Stemberg M. Alternative source of protein for fishmeal in Salmonid diets. In: Halver JE, Tiews $\mathrm{K}$ (eds) Fish nutrition and fish feed technology Hamberg, Berlin 1979; 2: 132-139.

29. Nandeesha MC, Srikath GK, Varghese TJ, et al. Growth performance of an Indian major carp Catla catla (Ham) on fishmeal free diets. In: Fish Nutrition Research in Asia. Proceedings of the third Asian Fish Nutrition Network meeting. Asian Fisheries Society Special Publication. Manila, Phillipines. 1989. 4: 137-142.

30. Portella MC, Verani JR, Cestarolli MA. Use of live and artificial diets enriched with several fatty acid sources to feed Prochilobus scrofalarvae and fingerlings. Effect of survival and growth. J Aquac Trop. 2000; 15: 45-58.

31. FAO. The State of World Fisheries and Aquaculture 2010. Food and Agriculture Organization of the United Nations. 2010 Rome.

\section{*Correspondence to:}

Javan Ominde

Department of Fisheries and Natural Resources,

Maseno University

Maseno, Kisumu

Kenya

E-mail: javanominde@gmail.com 